\title{
Blood Glucose Control and Insulin Clearance in Unrestrained Diabetic Dogs Portally Infused with a Portable Insulin Delivery System
}

\author{
Y. Goriya ${ }^{1}$, A. Bahoric ${ }^{1}$, E. B. Marliss ${ }^{2}$, B. Zinman ${ }^{2}$, and A. M. Albisser ${ }^{1,2}$ \\ ${ }^{1}$ The Hospital for Sick Children and ${ }^{2}$ The University of Toronto, Toronto, Ontario, Canada
}

Summary. Long term glucose control in pancreatectomised dogs has been obtained with portal insulin therapy. When compared to a previous similar study using peripheral infusions, $20 \%$ less exogenous insulin was required and peripheral fasting insulin levels were $30 \%$ lower. Animals $(\mathrm{n}=5)$ were unrestrained, conscious and carried a programmable insulin pump for 163-224 days. In the post-absorptive state blood glucose was normal $(87 \pm 5 \mathrm{mg} / \mathrm{dl})$ as was plasma insulin $(10 \pm 1 \mathrm{mU} / \mathrm{l})$ with porcine insulin infused at a basal rate of $0.36 \pm 0.01 \mathrm{mU} / \mathrm{kg} / \mathrm{min}$. Following ingestion of a standard mixed meal the infusion rate was increased to $2.47 \pm 0.09 \mathrm{mU} / \mathrm{kg} /$ $\min$ for $7^{1 / 2} \mathrm{~h}$ resulting in post-prandial normalisation of blood glucose. Peripheral plasma insulin levels were twice normal during the post-prandial infusion, but only half those previously reported with peripheral infusions. Insulin clearance rates were $37 \mathrm{ml} / \mathrm{kg} / \mathrm{min}$ in the basal state and rose significantly post-prandially. In the absence of extra meal-time insulin the clearance rate was unaffected by the resulting post-prandial hyperglycaemia and similar to values observed with insulin infused peripherally at $0.45 \pm 0.03 \mathrm{mU} / \mathrm{kg} / \mathrm{min}$. No significant increase in the post-prandial rate of insulin clearance relative to the fasting rate was observed with peripherally administered insulin. It was thus concluded that portal insulin replacement in pancreatectomised dogs could normalise both blood glucose and insulin in the fasting state, but post-prandial peripheral insulin levels remained elevated.

Key words: Glucose, insulin, infusion, hepatic degradation, insulin clearance, portal.

Long term blood glucose control in experimental diabetes is now feasible. Using a prototype portable insulin delivery device, glucose regulation has been obtained in pancreatectomised dogs for up to 12 months [1-3].

Similar open-loop studies of shorter duration (1-2 weeks) on insulin dependent diabetic patients have been reported with peripheral intravenous [4-8] and subcutaneous [9] insulin infusions. With peripherally infused insulin, such ideal blood glucose control is achieved only with concomitant peripheral hyperinsulinaemia [7] unless the subjects are adult, non-insulin requiring diabetics [10]. Studies in dogs showed similar results with peripheral $[11,12]$ but not with portal $[12,13]$ insulin infusions.

To explore more fully the route of insulin delivery as the cause of the observed hyperinsulinaemia the present series of experiments were conducted. They were aimed at restoring normoglycaemia in pancreatectomised dogs using the portal (natural) route for long-term preprogrammed insulin delivery. We have also examined the resulting insulin clearance rates in both the fasting and post-prandial states and contrasted these against data from similar studies [2] in which insulin was infused peripherally.

\section{Materials and Methods}

\section{Animals}

Five healthy male beagle dogs weighing $14.0 \pm 0.8 \mathrm{~kg}$ were used as normal controls, and five similar animals $(13.9 \pm 0.3 \mathrm{~kg})$ were totally pancreatectomised. A fixed amount of food was given to both groups each morning. The meal consisted of a mixture of two dog foods which included $360 \mathrm{~g}$ of soft meal (Meat Mix, Derby Pet Foods Ltd., Toronto) and $260 \mathrm{~g}$ of dry chow (Master Premium Dinner, Maple Leaf Mills Ltd., Toronto). The meal was approximately distributed as $33 \%$ protein, $30 \%$ fat, and $37 \%$ carbohydrate, the calculated total caloric content being about $1300 \mathrm{kcal} /$ day. Besides the above standard diet, it capsules of digestive enzymes (Cotazym, Organon Ltd., Montreal, Quebec) were mixed with the meals of the depancreatised dogs to compensate for their surgically induced pancreatic exocrine insufficiency. The diabetic 
dogs had normal stools and maintained their weight. Several animals have been maintained on porcine insulin preparations for over 3 years without the development of anti-insulin antibodies insofar as this would be reflected as changes in immunoreactive non-specific insulin binding in the assay method used. All dogs were confined to their cages but were allowed access to water ad libitum.

In diabetic dogs, fasting blood glucose concentrations were measured on 5 days per week and based on these measurements the portal basal insulin infusion rates were initially adjusted individually to achieve normoglycaemia in the morning.

\section{Catheterisation}

An indwelling silastic catheter was inserted into an external jugular vein of both the normal and diabetic dogs [14]. Similarly a chronic indwelling catheter for insulin infusion was inserted directly into the portal vein of the diabetic dogs at the time of pancreatectomy. It was attached with purse-string sutures directly to the vein as well as being sutured to adjacent connective tissues so as to cause minimal disturbance to portal blood flow while reducing the possibility of slipping out. The tip of the catheter was placed 3 to $4 \mathrm{~cm}$ distal to the porta hepatis so that insulin was delivered into the liver as uniformly as possible. Both catheters were tunnelled beneath the skin to outlet sites on the back and entered the pockets of vest-like jackets which the dogs wore.

\section{Portable Insulin Delivery System}

The portable insulin delivery device consisted of a miniature peristaltic pump, a polyvinyl chloride insulin reservoir and a batterypower-pack which included a flow-rate controller, details of which have been published elsewhere [2, 15]. The flow-rate controller [16] regulated by means of digital switch settings both the rate and the duration of a single square-wave pulse of insulin infusion as well as the rate of the chosen basal insulin infusion. The controller operated the pump every 90 seconds. Thus, insulin was infused in pulses of constant rate (approx. $80 \mu \mathrm{l} / \mathrm{min}$ ) the duration of which varied according to the switch settings chosen for the basal or meal rates. Preprogrammed meal insulin infusion was initiated by activating a magnetic reed switch with an external permanent magnet within $5 \mathrm{~min}$ of the presentation of the meal. Following the termination of this meal insulin infusion the flow-rate controller automatically returned to the present basal rate. Reservoirs were filled to capacity with porcine crystalline zinc insulin (Connaught Laboratories, Toronto) diluted in $\mathrm{pH}$ adjusted $0.154 \mathrm{~mol} / \mathrm{l}$ saline to a final concentration of $1240 \mathrm{U} / \mathrm{l}$. With these parameters the required basal rate was achieved with pulses that lasted 4-5 s.

\section{Protocols}

a) Meal Response in Normal Dogs. The standardised diet was given to the five normal dogs at time 0 (around $0900 \mathrm{~h}$ ) and always eaten within $5 \mathrm{~min}$. Blood samples were taken via the indwelling sampling catheter hourly from -1 to $13 \mathrm{~h}$ with additional samples at $14,15,16,17,19,21$ and $23 \mathrm{~h}$. Normal dogs were studied once.

b) Meal Response in Diabetic Dogs Given Basal Portal Insulin Infusions. The diabetic dogs were fed and blood was drawn in the same way as in the normal animals. During the meal period, insulin was delivered only at the basal rate for each dog.

c) Meal Response in Diabetic Dogs Given Basal plus Supplementary Portal Insulin Infusions. As in earlier experiments with peripheral insulin infusions [2] preliminary studies were undertaken to estimate the most suitable parameters (rate and duration) of the single pulse infusion of meal insulin. According to the observations in a preliminary series of experiments a portal meal insulin infusion rate of 7 times the basal rate ( $7 \mathrm{XB}$ ) for $7 \frac{1}{2} \mathrm{~h}$ was found to be appropriate to normalise post-prandial glycaemia. After this time the infusion automatically reset to the previous basal insulin delivery rate. Dogs I and IV were studied once, dogs II and V were studied 3 times and dog III was studied twice, but on widely separated occasions, for a total of 10 trials $61 \pm 14$ days (range 19-149) after the start of the portal infusion which lasted for 210 \pm 11 days (range $164-224$ ). The results reported are only from dogs which ate all the food within $5 \mathrm{~min}$ of its presentation. Blood samples were taken as before, for $13 \mathrm{~h}$ following the meal and then one final $23 \mathrm{~h}$ sample the next morning.

d) Insulin Clearance Rates. The clearance rates of insulin were calculated by dividing the exogenous insulin infusion rate by the resulting mean peripheral plasma insulin concentration both in the fasting and in the post-prandial states.

\section{Analytical Methods}

Blood samples were immediately transferred into $1.5 \mathrm{ml}$ centrifuge tubes kept on ice and containing $0.03 \mathrm{ml}$ of heparin $(1000 \mathrm{U} / \mathrm{ml})$. Samples were centrifuged with minimal delay, the supernatants separated and analysed for glucose using a Beckman glucose analyser or frozen at $-20 \mathrm{C}$ until subsequent insulin assay using an anti-pork insulin anti-serum (supplied by Dr. Peter Wright, Minneapolis, Minn.) purified pork insulin standard $(25.7 \mathrm{U} / \mathrm{mg}$, $125 \mathrm{I}$ labelled pork insulin, Novo) and a dextran coated charcoal separation of free from bound hormone. Pork and dog insulins bind in a similar fashion to the antibody used in this assay.

Statistical methods included the Student unpaired t-test to assess the significance of the differences between the mean responses of the normal and the diabetic dogs. All data shown here are expresses as mean \pm SEM.

\section{Results}

The $24 \mathrm{~h}$ profiles of plasma glucose and insulin concentrations of normal dogs fed the standard diet at time 0 are shown in Figure 1. Plasma glucose levels changed little throughout the experiment and remained within the range of $80 \pm 5$ to $96 \pm 3 \mathrm{mg} / \mathrm{dl}$. Post-prandial plasma insulin levels rose from basal levels of $10 \pm 1 \mathrm{mU} / 1$ to a peak of $33 \pm 4 \mathrm{mU} / 1$ at $3 \mathrm{~h}$ but remained significantly above the fasting levels for $17 \mathrm{~h}$ before returning to fasting levels.

With a basal insulin infusion rate of $0.36 \pm$ $0.01 \mathrm{mU} / \mathrm{kg} / \mathrm{min}$, the diabetic dogs were normoglycaemic in the morning $(90 \pm 6 \mathrm{mg} / \mathrm{dl}$ ) (Fig. 1). Plasma glucose levels rose rapidly after the meal and reached a peak of $465 \pm 42 \mathrm{mg} / \mathrm{dl}$ at $5 \mathrm{~h}$ and then gradually fell reaching levels of $96 \pm 21 \mathrm{mg} / \mathrm{dl}$ by the next morning. Fasting plasma insulin concentrations were $11 \pm 1 \mathrm{mU} / \mathrm{l}$ without significant post-prandial change and remained within the range of $9 \pm 1$ to 13 $\pm 1 \mathrm{mU} / \mathrm{l}$ over the entire $24 \mathrm{~h}$ period.

Starting from normoglycaemic levels of $87 \pm$ $5 \mathrm{mg} / \mathrm{dl}$ in the fasting state, post-prandial plasma glucose concentrations during the meal insulin infusion 

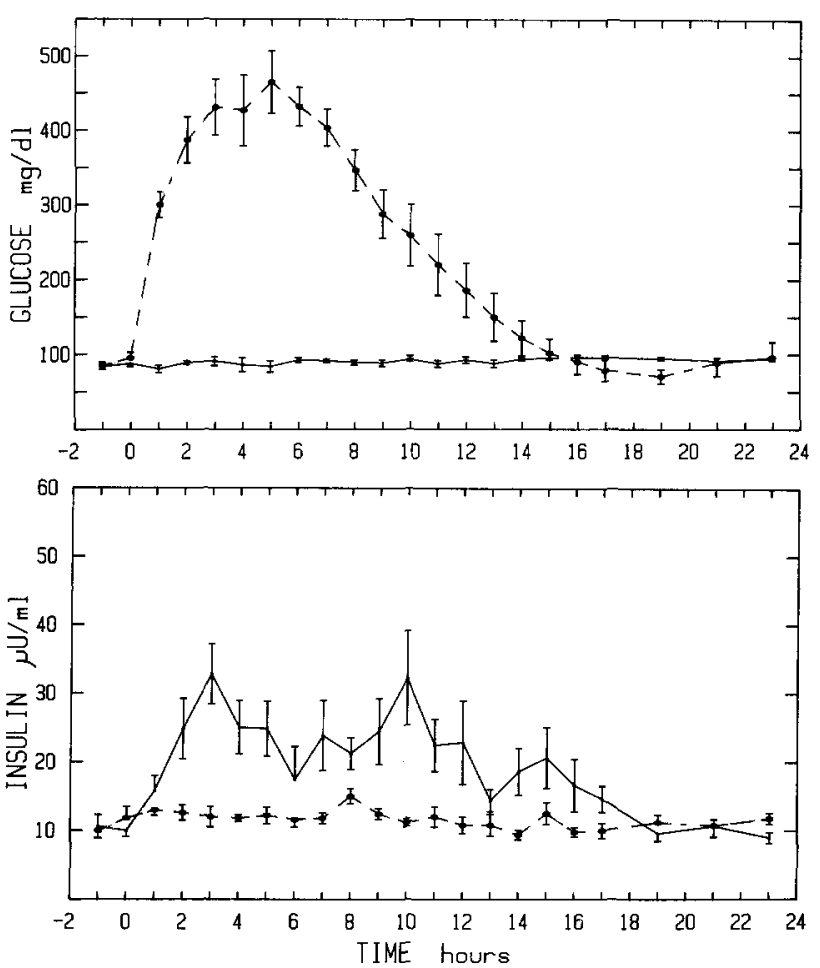

Fig. 1. Mean \pm SEM glucose and insulin responses to a mixed meal in unrestrained healthy beagle dogs $(\mathrm{n}=5)$, and in pancreatectomised dogs ( $n=5$, broken line) infused portally with constant basal insulin only. The meal $(620 \mathrm{~g})$ was presented at $t=0$

remained within the normal range in the diabetic dogs reaching a nadir of $79 \pm 12 \mathrm{mg} / \mathrm{dl}$ at the end of the meal insulin (Fig. 2). Following the termination of the $7 \frac{1}{2} \mathrm{~h}$ supplementary meal insulin pulse, plasma glucose rose to $136 \pm 18 \mathrm{mg} / \mathrm{dl}$ but returned to normoglycaemic levels within $3 \mathrm{~h}$. Fasting levels of $73 \pm 4 \mathrm{mg} / \mathrm{dl}$ were observed next morning. These were significantly lower than the initial levels $(\mathrm{p}<$ 0.001 ). The basal insulin infusion rate was $0.36 \pm$ $0.01 \mathrm{mU} / \mathrm{kg} / \mathrm{min}$ and was increased to $2.47 \pm$ $0.09 \mathrm{mU} / \mathrm{kg} / \mathrm{min}$ for $7 \frac{1}{2} \mathrm{~h}$ in the post-prandial period. Fasting plasma insulin concentrations were $10 \pm 1 \mathrm{mU} / 1$ and rose during the meal insulin infusion to levels ranging from $42 \pm 4$ to $50 \pm 4 \mathrm{mU} / \mathrm{l}$, significantly higher than normal $(\mathrm{p}<0.001)$. Following the end of the meal insulin infusion, insulin levels fell to near basal values within $30 \mathrm{~min}$ and remained in this range throughout the remainder of the experiment.

The individual portal infusion rates, the resulting mean peripheral insulin levels and the corresponding insulin clearance rates in the fasting and post-prandial states for each experiment are presented in Tables 1 and 2 respectively for the basal only and basal plus supplementary meal insulin infusions. In
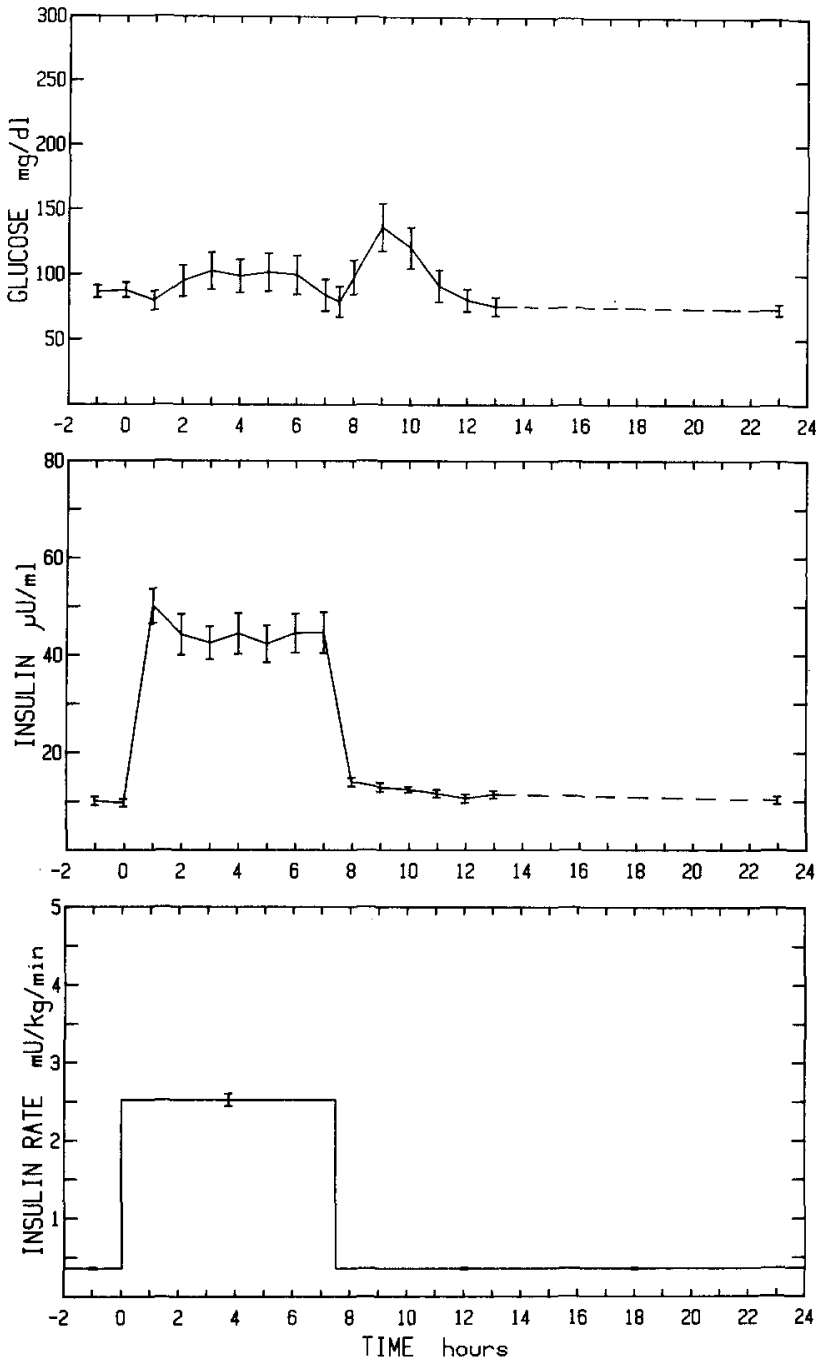

Fig. 2. The glucose and insulin responses of five unrestrained pancreatectomised beagle dogs (total trials $=10$ ) given basal and supplementary meal intraportal insulin infusion according to the waveform in the lower panel (meal pulse is 7 times basal for $7^{1 / 2} \mathrm{~h}$ ). Treatment was continued in each dog for 5 to 7 months using a portable insulin infusion device. Meal timing as in Figure 1

the fasting state insulin clearance rates were consistent in the portally infused diabetic dogs the mean specific rates being $35 \pm 5$ and $37 \pm 3 \mathrm{ml} / \mathrm{kg} / \mathrm{min}$. These values were similar to the $34 \pm 4$ and $32 \pm$ $2 \mathrm{ml} / \mathrm{kg} / \mathrm{min}$ observed with peripheral insulin infusions [2], data for which is presented in these tables for comparison. See Tables 1 and 2 .

In the post-prandial period insulin clearance showed an insignificant drop of $-5 \mathrm{ml} / \mathrm{kg} / \mathrm{min}$ when the portal insulin infusion was maintained at the basal rate but rose significantly by $+21 \mathrm{ml} / \mathrm{kg} / \mathrm{min}$ (p $<0.001$ ) with the enhanced meal insulin infusion. In contrast, when post-prandial insulin was infused 
peripherally, the insulin clearance rates changed only slightly rising $+3 \mathrm{ml} / \mathrm{kg} / \mathrm{min}$ (not significant) with basal only insulin and only $+6 \mathrm{ml} / \mathrm{kg} / \mathrm{min}$ (not significant) with the enhanced meal infusion.

Table 1. Portal insulin infusion rates, peripheral plasma insulin concentrations and calculated insulin clearance rates in the fasting and post-prandial states with basal only insulin delivery

\begin{tabular}{|c|c|c|c|c|c|}
\hline \multirow[b]{2}{*}{$\begin{array}{l}\text { Dog } \\
\text { no. }\end{array}$} & \multicolumn{3}{|l|}{ Fasting } & \multicolumn{2}{|c|}{ Post-prandial } \\
\hline & $\begin{array}{l}\text { Insulin } \\
\text { infusion } \\
\text { rate } \\
\mathrm{mU} / \mathrm{kg} / \mathrm{min}\end{array}$ & $\begin{array}{l}\text { Plasma } \\
\text { insulin } \\
\text { level } \\
\text { mU/1 }\end{array}$ & $\begin{array}{l}\text { Clearance } \\
\text { rate } \\
\mathrm{ml} / \mathrm{kg} / \mathrm{min}\end{array}$ & $\begin{array}{l}\text { Plasma } \\
\text { insulin } \\
\text { level } \\
\mathrm{mU} / 1\end{array}$ & $\begin{array}{l}\text { Clearance } \\
\text { rate } \\
\mathrm{ml} / \mathrm{kg} / \mathrm{min}\end{array}$ \\
\hline I & 0.40 & 12.0 & 33 & 11.0 & 36 \\
\hline II & 0.32 & 12.0 & 27 & 13.0 & 25 \\
\hline III & 0.28 & 13.5 & 21 & 13.6 & 20 \\
\hline IV & 0.41 & 10.5 & 39 & 13.0 & 31 \\
\hline V & 0.38 & 7.0 & 55 & 9.6 & 40 \\
\hline \multicolumn{6}{|c|}{ Portal insulin infusion $(A)$} \\
\hline Mean & 0.36 & 11.0 & 35 & 12.0 & 30 \\
\hline \pm SEM & 0.03 & 1.1 & 6 & 0.7 & 3 \\
\hline \multicolumn{6}{|c|}{ Peripheral insulin infusion $(B)$} \\
\hline Mean & 0.46 & 14.2 & 34 & 12.6 & 37 \\
\hline$\pm \mathrm{SEM}$ & 0.04 & 1.4 & 4 & 1.0 & 4 \\
\hline$A$ vs $B^{\text {a }}$ & & $\mathrm{n}$ & & ns & Is \\
\hline
\end{tabular}

$B=$ data from [2], $\mathrm{n}=11$

${ }^{\mathrm{a}} \mathrm{p}<0.05, \mathrm{~ns}=$ not significant

\section{Discussion}

Mixed meals in normal dogs produced no change in blood glucose (Fig. 1). Previously we demonstrated [2] that this unusual glucose control could be restored in pancreatectomised dogs by peripheral open-loop insulin infusions. Glucose control by this route was however always accompanied by hyperinsulinaemia $[2,11]$. In order to explore the effects of the route of insulin delivery, essentially identical experimental protocols were undertaken in diabetic dogs in the present study except that insulin infusion was directed portally instead of peripherally. When basal insulin infusion rates were compared, it was found that the portal rate was significantly lower than the peripheral rate $(0.36 \pm 0.01$ vs $0.45 \pm 0.03 \mathrm{mU} / \mathrm{kg} /$ min, $\mathrm{p}<0.05$ ) in spite of similar fasting glucose levels. The basal rates used in these studies are similar to the estimated endogenous insulin release [17] of the fasting anaesthetised dog and agree with the intraportal replacement infusion rate required to maintain normal basal levels when endogenous secretion is suppressed by infusion of somatostatin in the same dog model [18]. Interestingly, similar postprandial blood glucose control was obtained with the same seven-fold basal increase in meal insulin infusion rate with both routes, but $20 \%$ less insulin was needed with portal compared to peripheral insulin

Table 2. Portal insulin infusion rates, plasma insulin concentrations and insulin clearance rates in the fasting and post-prandial states with basal and supplementary meal insulin delivery

\begin{tabular}{|c|c|c|c|c|c|c|}
\hline \multirow[b]{2}{*}{$\begin{array}{l}\text { Dog } \\
\text { no. }\end{array}$} & \multicolumn{3}{|l|}{ Fasting } & \multicolumn{3}{|l|}{ Post-prandial } \\
\hline & $\begin{array}{l}\text { Infusion rate } \\
\mathrm{mU} / \mathrm{kg} / \mathrm{min}\end{array}$ & $\begin{array}{l}\text { Insulin } \\
\mathrm{mU} / 1\end{array}$ & $\begin{array}{l}\text { Clearance rate } \\
\mathrm{ml} / \mathrm{kg} / \mathrm{min}\end{array}$ & $\begin{array}{l}\text { Infusion rate } \\
\mathrm{mU} / \mathrm{kg} / \mathrm{min}\end{array}$ & $\begin{array}{l}\text { Insulin } \\
\mathrm{mU} / 1\end{array}$ & $\begin{array}{l}\text { Clearance rate } \\
\mathrm{ml} / \mathrm{kg} / \mathrm{min}\end{array}$ \\
\hline I & 0.36 & 9.0 & 40 & 2.50 & 43.1 & 58 \\
\hline II-1 & 0.37 & 8.0 & 46 & 2.56 & 31.7 & 81 \\
\hline II-2 & 0.33 & 9.3 & 35 & 2.23 & 38.7 & 59 \\
\hline II-3 & 0.32 & 11.0 & 29 & 2.26 & 39.2 & 58 \\
\hline III-1 & 0.35 & 14.0 & 25 & 2.42 & 61.4 & 40 \\
\hline III-2 & 0.29 & 12.3 & 23 & 1.99 & 34.7 & 57 \\
\hline IV & 0.41 & 9.7 & 42 & 2.62 & 60.9 & 43 \\
\hline$V-1$ & 0.41 & 10.0 & 41 & 2.89 & 52.2 & 55 \\
\hline $\mathrm{V}-2$ & 0.40 & 9.0 & 44 & 2.83 & 55.7 & 51 \\
\hline$V-3$ & 0.33 & 7.0 & 47 & 2.31 & 32.6 & 71 \\
\hline \multicolumn{7}{|c|}{ Portal insulin infusion $(A)$} \\
\hline Mean & 0.36 & 9.9 & 37 & 2.52 & 44.5 & 58 \\
\hline \pm SEM & 0.01 & 0.6 & 3 & 0.08 & 3.5 & 4 \\
\hline \multicolumn{7}{|c|}{ Peripheral insulin infusion $(B)$} \\
\hline Mean & 0.45 & 14.2 & 32 & 3.13 & 83.5 & 38 \\
\hline \pm SEM & 0.03 & 0.8 & 2 & 0.23 & 6.5 & 2 \\
\hline$A$ vs $B$ & a & c & a & a & c & a \\
\hline
\end{tabular}

$B=$ data from $[2] \mathrm{n}=11$

${ }^{\mathrm{a}} \mathrm{p}<0.05$

b $p<0.01$

c $\mathrm{p}<0.001$ 
delivery when the diabetic dogs were accustomed to the particular route. These observations are undoubtedly related to the central role of the liver in glucose regulation [19-21].

There have been several reports which compared the effects of the routes of insulin delivery. Some [12, 22] claimed that there was no change between portal and peripheral infusion while others [23-27] reported that peripheral insulin infusion was more effective, and vice versa [28, 29]. These inconsistencies in the reported results may well be a consequence of the different experimental protocols, including different experimental stimulatory actions, baseline conditions, and methods of data assessment.

Fasting insulin concentrations in portally infused diabetic dogs were identical to those of the normal controls but significantly lower than those of peripherally infused diabetic dogs $(9.9 \pm 0.6$ vs 14.2 $\pm 0.8 \mathrm{mU} / \mathrm{l}, \mathrm{p}<0.001$, Table 2). Table 1 presents similar differences but these failed to reach statistical significance due to the smaller number of experiments. Approximately twice normal post-prandial insulin concentrations were observed in dogs with portally infused insulin. With peripheral delivery these were 2-4 $\times$ normal [2].

Portal insulin infusion [13] has been reported not to have produced hyperinsulinaemia while peripheral insulin infusion did $[2,11]$. Why a mild but significant hyperinsulinaemia was observed during the postprandial period in the present experiments despite the physiological route of optimal insulin delivery is not clear. In the present series of experiments the diabetic dogs were given not glucose solutions but their usual mixed meal composed of protein, fat and carbohydrate and they were unrestrained in the conscious state and adapted to long-term portal insulin replacement. Previous experiments [12, 22-29] were done either in the conscious fasting state only or in the anaesthetised state with glucose given intravenously. Also, the portable insulin delivery device gave variable duration pulses of insulin every $90 \mathrm{sec}-$ onds [16]. Whether this type of pulsed intermittent insulin infusion allowed more insulin to escape hepatic extraction and thereby caused the observed mild hyperinsulinaemia has not been clearly established, although there is some evidence to this effect with peripheral infusion [30]. Other unknown factor(s) may also play an important role in the regulation of insulin degradation and/or clearance. Finally, there may be a lack of adequate mixing of the infused insulin with the following portal blood but the mechanics of blood flow within the liver [31] should compensate for poor mixing.

Insulin clearance did not change post-prandially with basal only insulin delivery via either the portal or peripheral routes (Table 1). With supplementary meal insulin delivery the clearance rate rose significantly only in the portal studies (Table 2).

In conclusion, portal insulin administration with an external insulin delivery device restored glycaemic regulation in pancreatectomized dogs with $20 \%$ less insulin and $30 \%$ lower resulting plasma insulin concentrations than in similar studies with peripheral insulin. Notwithstanding these improvements twofold normal insulin levels were still seen during the post-prandial state. Insofar as the data obtained with portally infused insulin are representative of the physiological state, the clearance of peripherally administered insulin may be grossly abnormal in spite of the complete glycaemic normalisation achieved by either route. Taking into consideration the adverse effects of hyperinsulinaemia upon insulin receptors $[32,33]$, lipolysis [34], and metabolism [35, 36] it remains to be established whether this mild mealassociated peripheral hyperinsulaemia is harmful in the long-term. Preliminary studies indicate that this is the case [37].

Acknowledgements. The Artificial Endocrine Pancreas Program is supported by grant MA5767 from the Medical Research Council of Canada and Negotiated Contract NO1-AM-0-2201 from the National Institutes of Health in Bethesda, Maryland. We wish to thank the Departments of Animal Care and Surgical Research at The Hospital for Sick Children and the Metabolic Laboratory under the supervision of Dr. E. B. Marliss at the University of Toronto for their cooperation and assistance in producing the results presented here. The manuscript was prepared by Debra Edwards.

\section{References}

1. Albisser AM, Bahoric A, Goriya Y, Jackman WS, Ferguson T, Leibel BS (1978) Control of experimental diabetes using a portable insulin delivery system. Diabetes 27 (Suppl 2): 439

2. Goriya Y, Bahoric A, Marliss EB, Albisser AM (1979) Glycemic regulation using a programmed insulin delivery device. III. Long-term studies on diabetic dogs. Diabetes 28: 558-564

3. Albisser AM, Goriya Y, Bahoric A, Marliss EB (1979) Glycemic normalization using a preprogrammed insulin delivery device in unrestrained diabetic dogs. In: Camerini Davalos RE, Hanover B (eds) Early diagnosis of diabetes. Plenum Publishing, New York, London, 509-514

4. Slama G, Hautecouverture M, Assan R, Tchobroutsky G (1974) One to five days of continuous intravenous insulin infusion on seven diabetic patients. Diabetes 23: 732-738

5. Deckert T, Lorup B (1976) Regulation of brittle diabetics by a preplanned insulin infusion programme. Diabetologia 12: 573-579

6. Service FJ (1978) Normalization of plasma glucose of unstable diabetes: studies under ambulatory, fed conditions with pumped intravenous insulin. J Lab Clin Med 91: 480-489

7. Hanna AK, Minuk HL, Albisser AM, Marliss EB, Leibel BS, Zinman B (1980) A portable system for continuous intravenous insulin delivery: characteristics and results in diabetic patients. Diabetes Care 3: $1-8$ 
8. Irsigler K, Kritz H (1979) Long term continuous insulin therapy with a portable insulin dose regulating apparatus. Diabetes 28: 196-203

9. Pickup JC, Keen H, Parsons JA, Alberti KGMM (1978) Continuous subcutaneous insulin infusion: an approach to achieving normoglycaemia. Br Med J I: 204-207

10. Genuth S, Martin P (1977) Control of hyperglycemia in adult diabetics by pulsed insulin delivery. Diabetes 26: 571-581

11. Botz CK, Marliss EB, Albisser AM (1979) Blood glucose regulation using closed- and open-loop insulin delivery systems. II. Peripheral primed square waves. Diabetologia 17: 45-49

12. Botz CK, Leibel BS, Zingg W, Gander RE, Albisser AM (1976) Comparison of peripheral and portal routes of insulin infusion by a computer controlled insulin infusion system (artificial endocrine pancreas). Diabetes 25: 691-700

13. Albisser AM, Botz CK, Leibel BS (1979) Blood glucose regulation using an open-loop insulin delivery system in pancreatectomized dogs given glucose infusions. I. Portal square waves. Diabetologia 16: 129-133

14. Bahoric A, Filler RM, Perlman K, Jackman WS, Albisser AM (1980) New devices and methods for long term vascular access for blood sampling and insulin infusion. Diabetes Care 3 : 338-344

15. Jackman WS, Lougheed W, Marliss EB, Zinman B, Albisser AM (1980) For insulin infusion: A miniature precision peristaltic pump and silicone rubber reservoir. Diabetes Care 3 : 322-331

16. Ferguson T, Zinman B, Marliss EB, Albisser AM (1980) An electronic flow rate controller for a portable insulin infusion pump. Diabetes Care 3: 332-337

17. Kaden M, Harding P, Field JB (1973) Effect of intraduodenal glucose administration on hepatic extraction of insulin in the anesthetized dog. J Clin Invest 52: 2016-2028

18. Cherrington AD, Chiasson JL, Liljenquist JE, Jennings AS, Keller U, Lacy WW (1976) The role of insulin and glucagon in the regulation of basal glucose production in the postabsorptive dog. J Clin Invest 58: 1407-1418

19. Felig $P$ (1974) Insulin: rates and routes of delivery. N Engl J Med 291: 1031-1032

20. Felig P, Wahren J (1971) Influence of endogenous insulin secretion on splanchnic glucose and amino acid metabolism in man. J Clin Invest 50: 1702-1711

21. Chiasson JL, Liljenquist JE, Finger FE, Lacy WW (1976) Differential sensitivity of glycogenolysis and gluconeogenesis to insulin infusions in dogs. Diabetes 25: 287-291

22. Starzl TE, Burtz GW Jr, Meyer WH Jr, Torok EE, Dolkart RE (1962) Effect in dogs of various portal vein shunts in response to insulin. Am J Physiol 203: 275-277

23. Galansioni G, D'Amico G, Kanameishi D, Foa PP (1958) Mode of action of insulin, carbutamide and tolbutamide. PSEB (NY) 99: 447-450

24. Martin FIR, Leonards JR, Miller M (1959) A comparison of the effect of the intraportal and intravenous administration of $\mathrm{I}^{131}$-insulin on peripheral blood glucose and serum radioactivity. Metabolism 8: 472-478

25. Erwald R, Hed R, Nygren A, Rojdmark S, Wirchel KL (1974) Comparison of the effect of intraportal and intravenous infu- sion of insulin on blood glucose and free fatty acids in peripheral venous blood of man. Acta Med Scand 195: 315-357

26. Baruch S (1975) The physiologic significance of portal vs peripheral injection of insulin in man. Am $\mathbf{J}$ Med Sci 269: 25-35

27. Stevenson RW, Parsons JA, Alberti KGMM (1978) Insulin infusion into the portal and peripheral circulations of unanaesthetized dogs. Clin Endocrinol (Oxf) 8: 335-347

28. Madison LL, Unger RH (1958) The physiologic significance of the secretion of endogenous insulin into the portal circulation. I. Comparison of the effects of glucagon-free insulin administered via the portal vein on the magnitude of hypoglycemic and peripheral glucose utilization. J Clin Invest 37: 631-639

29. Madison LL, Combes B, Adams R, Strickland W (1960) The physiologic significance of the secretion of endogenous insulin into the portal circulation. III. Evidence for a direct immediate effect of insulin on the balance of glucose across the liver. J Clin Invest 39: 507-522

30. Salzieder E, Fischer U, Mester J, Freizse E-J, Gotschling HD, Albrecht G (1977) Konstant dosierte intravenöse Insulininfusionen: Plasmainsulin und Glukose unter dem Einfluß differenter Infusionszeitraster beim Hund. IX Karlsburg Symposium on Problems of Diabetes, Proceedings, p 178-179

31. Rappaport AM (1973) The microcirculatory hepatic unit. Microvasc Res 6: 212-221

32. Olefsky JM, Reaven GM (1977) Insulin binding in diabetes. Relationships with plasma insulin levels and insulin sensitivity. Diabetes 26: 680-688

33. Livingston JM, Purvis BJ, Lockwood DJ (1978) Insulindependent regulation of the insulin-sensitivity of adipocytes. Nature 273: 394-396

34. Lavis VR, Williams RH (1973) Lipolytic effects of high concentrations of insulin on isolated fat cells. Enhancement of the response to lipolytic hormones. Diabetes 22: 629-636

35. Zinman B, Stokes EF, Albisser AM, Hanna AK, Minuk HL, Stein AN, Leibel BS, Marliss EB (1979) The metabolic response to glycemic control by the artificial pancreas in diabetic man. Metabolism 28: 511-518

36. Hanna AK, Nakhooda AF, Minuk HL, Stokes EF, Albisser AM, Leibel BS, Zinman B, Marliss EB Z1980) Insulin, glucagon and amino acid levels during glycemic control by the artificial pancreas in diabetic man. Metabolism (in press)

37. Albisser AM, Bahoric A, Goriya Y (1980) Hyperinsulinism in the dog: The metabolic and hormonal consequences of chronic exogenous insulin infusion. Diabetes 29 (Suppl 1): 241

Received: February 18, 1980,

and in revised form: June 4, 1980

A. M. Albisser

Biomedical Research

The Hospital for Sick Children

555 University Avenue

Toronto M5G IX8

Canada 